der unteren Teilbänder ausbilden. Verschmelzen nun auch die übrigen d-Elektronen zu gemeinsamen oberen Teilbändern, was nach Bader durch die Periodizität des Potentials im Überstrukturgitter erleichtert wird, so stehen für diese oberen Teilbänder noch $11 / 3 \mathrm{~d}$ Elektronen pro Atom zur Verfügung. Die oberen Teilbänder sind also mehr als halb besetzt, so daß sich ein von 4/3 d-Lücken pro Atom herrührendes Sättigungsmoment von $4 \mu_{\mathrm{B}}$ für den Gitterbaustein $\mathrm{Cu}_{2} \mathrm{MnAl}$ ergibt.

Nach dieser Darstellung erfolgt im Gitter vom Al zum Mn ein Elektronenübergang, wie er kürzlich von Friedel ${ }^{5}$ eingehend theoretisch untersucht wurde. Bei gleichmäßig angenommener räumlicher Konzentration der 1,5 s-Elektronen pro Atom und gemeinsam von $\mathrm{Cu}$ - und $\mathrm{Mn}$-Atomen gebildetem d-Band errechnet sich folgende Ladungsverteilung:

\begin{tabular}{|l|c|c|c|}
\hline & $\mathrm{Al}$ & $\mathrm{Cu}$ & $\mathrm{Mn}$ \\
\hline Atomrumpf & +3 & $+2,33$ & $-1,66$ \\
Elektronengas & $-1,5$ & $-1,5$ & $-1,5$ \\
Atombereich & $+1,5$ & $+0,83$ & $-3,16$ \\
\hline
\end{tabular}

Das s-Elektronengas wird daher aus den Mn-Bereichen $\mathrm{zu}$ den $\mathrm{Cu}$ - und Al-Rümpfen hin ausweichen. Trotzdem behält das Gitter einen stark heteropolaren Charakter, wobei das Mangan Anion ist.

Ein Elektronenübergang von $\mathrm{Al}$ zu Mn findet übrigens auch in der Al-reichsten Phase der binären Reihe $\mathrm{MnAl}_{6}$ statt. Aus magnetischen Messungen von Lingelbach ${ }^{6}$ folgt, daß in dieser Phase die d-Schale des Mangans von den Valenzelektronen des Al sehr weitgehend, wenn nicht vollständig aufgefüllt wird ${ }^{7}$. Es ist der gleiche Vorgang, der in der Heusler-Legierung zum Ferromagnetismus, bei $\mathrm{MnAl}_{6}$ nahezu zum Diamagnetismus führt.

Hinsichtlich der hier vorgeschlagenen Deutung wäre die Bestimmung der Elektronendichteverteilung mittels röntgenographischer Fourier-Analyse und die Bestimmung der magnetischen Einzel-Atommomente mittels Neutronenbeugung von größtem Interesse.

5 J. Friedel, Ann. Phys., Paris; Thèses (Paris 1954).

${ }_{6}$ R. Lingelbach, Marburger Diplomarbeit 1954.

7 E. Vogt, Appl. Sci. Res. 1954 (Borelius-Festheft).

\section{Molecular Dipole Rotation and Association}

From Mansel Davies

The Edward Davies Chemical Laboratories, Aberystwyth, Wales

(Z. Naturforschg. 9a, 474 [1954]; eingeg. am 17. April 1954)

A paper by Fischer and Fessler ${ }^{1}$ is amongst the many interesting contributions which have recently appeared in this journal on the subject of dielectric absorption and its relation to molecular structure. These authors show from the relaxation times measured for aniline in $\mathrm{CCl}_{4}$ that the dipole in this case is not rigidly fixed to the molecular framework, i. e. $\tau$ (effective) $<\tau$ (rigid molecule). From the observed decrease of $\tau$ (effective) with increasing concentration in $\mathrm{CCl}_{4}$ they conclude that, (i) a special mechanism operates to facilitate the dipole reorientation in the concentrated solutions and, further, (ii)" auf keinen Fall aber weist Anilin eine Assoziation auf, die zu den üblicherweise anzunehmenden langlebigen Komplexen führt, welche gegenüber der Wirkung des äußeren Feldes als kinetische Einheiten anzusehen sind".

It so happens that (ii), i. e. the association of aniline in $\mathrm{CCl}_{4}$, has been the subject of special study on the basis of infra-red absorptions ${ }^{2}$. From these obser-

${ }^{1}$ E. Fischer and H. Fessler, Z. Naturforschg. 8a, 168 [1953].

${ }^{2}$ N.Fuson, M-L.Josien, R.L.Powell and E. Ut terback, J. Chem. Phys. 20, 145 [1952]; cf. also, W. Gordy, ibid. 7, 167 [1939]. vations it has been concluded that association certainly occurs. Many years ago ${ }^{3}$ the present writer evaluated this association by measuring the distribution of aniline between water and $\mathrm{CCl}_{4}$ over a range of concentrations and at a number of temperatures. The results are quantitatively represented ${ }^{4}$ by a dimerisation process, i. e. with the constant $K_{2}=[\mathrm{Mo}-$ nomer $]^{2} /[$ Dimer $]=2,5$ g. mol./litre at $25^{\circ} \mathrm{C}$, and $\Delta H_{2}$ $=1930$ cal./g. mol. dimer. The former equilibrium constant means that at 1.0 molar in $\mathrm{CCl}_{4}$ (mole fraction solute $\approx 0.10$ ) only 65 per cent. of the aniline molecules are monomeric.

Conclusion (i) may also be unjustifiable on the basis of the relation used by Fischer in similar simple cases, i. e.

$$
\tau(\text { effective })=\tau_{\mathrm{f}} \cdot \mu_{\mathrm{f}}^{2} / \mu^{2}+\tau_{\mathbf{r}} \cdot \mu^{2}{ }_{\mathrm{r}} / \mu^{2} ; \mu^{2}=\mu_{\mathrm{f}}{ }_{\mathrm{f}}+\mu^{2}{ }_{r},
$$

where $\tau_{f}$ ans $\tau_{r}$, etc. refer to the rigid and rotating components of the dipole molecule. On association each molecular species will have its own values for $\mu_{\mathrm{f}}, \tau_{\mathrm{f}}, \mu_{\mathrm{r}}, \tau_{\mathrm{r}}$, so that the observed variation of $\tau$ (effective) with concentration may possibly be due to the differences in these factors, e. g. the hypothetical condition $\mu_{\mathrm{f}}($ dimer $)=0, \tau_{\mathrm{r}}($ dimer $) \approx \tau_{\mathrm{r}}$ (monomer) would qualitatively fit the present case.

3 1941, unpublished, cf. Annual Reports chem. Soc. (London) 43, 6 [1946].

${ }^{4}$ cf. E. A. Moelwyn-Hughes, J. Chem. Soc. 1940, 850 . 